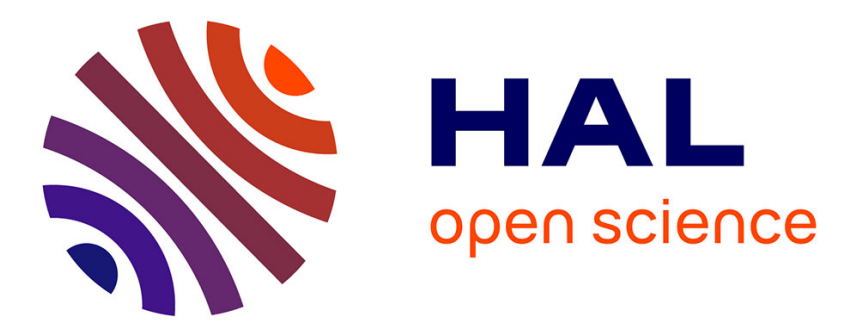

\title{
Attractancy of bacterivorous nematodes to root-adhering soils differs according to rice cultivars
}

Mahafaka Ranoarisoa, Eric Blanchart, Kirsten Vom Brocke, Alain

Ramanantsoanirina, Mathilde Sester, Claude Plassard, Laurent Cournac, Jean Trap

\section{To cite this version:}

Mahafaka Ranoarisoa, Eric Blanchart, Kirsten Vom Brocke, Alain Ramanantsoanirina, Mathilde Sester, et al.. Attractancy of bacterivorous nematodes to root-adhering soils differs according to rice cultivars. Rhizosphere, 2017, 3 (1), pp.128-131. 10.1016/j.rhisph.2017.04.001 . hal-01605972

\section{HAL Id: hal-01605972 \\ https://hal.science/hal-01605972}

Submitted on 25 May 2020

HAL is a multi-disciplinary open access archive for the deposit and dissemination of scientific research documents, whether they are published or not. The documents may come from teaching and research institutions in France or abroad, or from public or private research centers.
L'archive ouverte pluridisciplinaire $\mathbf{H A L}$, est destinée au dépôt et à la diffusion de documents scientifiques de niveau recherche, publiés ou non, émanant des établissements d'enseignement et de recherche français ou étrangers, des laboratoires publics ou privés.

\section{다(1)(2)}

Distributed under a Creative Commons Attribution - ShareAlikel 4.0 International 


\section{Author's Accepted Manuscript}

Attractancy of bacterivorous nematodes to rootadhering soils differs according to rice cultivars

Mahafaka Patricia Ranoarisoa, Eric Blanchart, Kirsten vom Brocke, Alain Ramanantsoanirina, Mathilde Sester, Claude Plassard, Laurent Cournac, Jean Trap

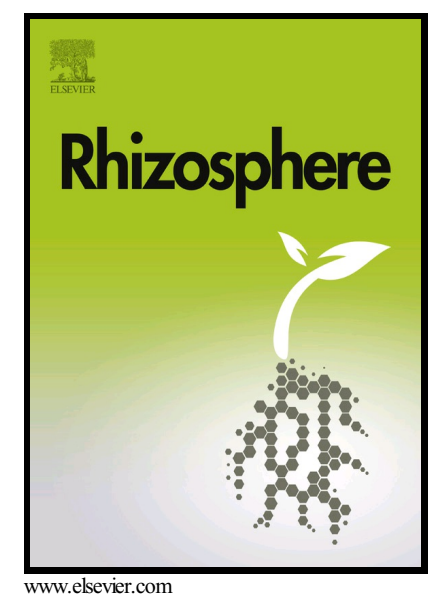

PII: S2452-2198(17)30043-5

DOI: $\quad$ http://dx.doi.org/10.1016/j.rhisph.2017.04.001

Reference: RHISPH45

To appear in: Rhizosphere

Received date: 24 February 2017

Revised date: 31 March 2017

Accepted date: 1 April 2017

Cite this article as: Mahafaka Patricia Ranoarisoa, Eric Blanchart, Kirsten vor Brocke, Alain Ramanantsoanirina, Mathilde Sester, Claude Plassard, Lauren Cournac and Jean Trap, Attractancy of bacterivorous nematodes to root-adhering soils differs according to rice cultivars, Rhizosphere http://dx.doi.org/10.1016/j.rhisph.2017.04.001

This is a PDF file of an unedited manuscript that has been accepted fo publication. As a service to our customers we are providing this early version $\mathrm{o}$ the manuscript. The manuscript will undergo copyediting, typesetting, an review of the resulting galley proof before it is published in its final citable form Please note that during the production process errors may be discovered whic could affect the content, and all legal disclaimers that apply to the journal pertain 


\section{ACCEPTED MANUSCRIPT}

Attractancy of bacterivorous nematodes to root-adhering soils differs according to rice

cultivars

Mahafaka Patricia Ranoarisoa ${ }^{1,2}$, Eric Blanchart ${ }^{1,2}$, Kirsten vom Brocke ${ }^{3}$, Alain

Ramanantsoanirina ${ }^{4}$, Mathilde Sester ${ }^{5}$, Claude Plassard ${ }^{6}$, Laurent Cournac ${ }^{7}$, Jean Trap ${ }^{1,2 *}$

${ }^{1}$ Laboratoire des Radio Isotopes, BP 3383, Route d'Andraisoro, Antananarivo 101,

Madagascar

${ }^{2}$ IRD, UMR Eco\&Sols, Laboratoire des Radio Isotopes, BP 3383, 101 Antananarivo,

Madagascar

${ }^{3}$ CIRAD, UR AGAP, SRR FOFIFA, BP 230, 110 Antsirabe, Madagascar

${ }^{4}$ SRR FOFIFA, BP 230, 110 Antsirabe, Madagascar

${ }^{5}$ CIRAD, UR AIDA, TA-B-115/02, Avenue Agropolis, 34398 Montpellier, France

${ }^{6}$ INRA, UMR Eco\&Sols, 2 place Viala, 34060 Montpellier Cedex 2, France

${ }^{7}$ IRD, UMR Eco\&Sols, LMI IESOL, Centre IRD/ISRA de Bel Air, BP 1386, Dakar, Senegal

*Corresponding author. Jean Trap, IRD, UMR Eco\&Sols, Laboratoire des Radio Isotopes, BP 3383, 101 Antananarivo, Madagascar, Tél : +261 (0)32.47.126.74, Email : jean.trap@ird.fr

\section{Abstract}




\section{ACCEPTED MANUSCRIPT}

We tested the ability of root-adhering soils (RAS) from eight rice cultivars to attract a bacterivorous nematode (Acrobeloides sp.) living in a poor-nutrient soil in Madagascar. We showed that the ability of rice to attract bacterivorous nematodes in its rhizosphere is variable among cultivars. FOFIFA 172 was the cultivar with the highest attraction value, the lowest root biomass $(\mathrm{RB})$ and the highest $\mathrm{RAS}: \mathrm{RB}$ ratio and RAS respiration. In contrast, nematodes exhibited strong repellent response to W880 RAS. Also, nematode attractancy was not related to rice resistance against pests (blast rice disease and Striga asiatica) neither to cultivar ability to grow at specific altitude. Our results suggest a trade-off in carbon allocation between plant biomass and root exudation driving nematode attractancy and raise questions about the impact of plant breeding on cultivar ability to interact with soil mutualists such as bacterivorous nematodes. Further investigations are required into (i) variation in root exudate quantity and composition among the eight cultivars and (ii) the response of rice cultivars to bacterivorous nematode inoculation.

Keywords: upland rice cultivar, Acrobeloides sp., nematode attractancy, ferrallitic soil, Madagascar. 


\section{ACCEPTED MANUSCRIPT}

\section{Main text}

Bacterivorous nematodes are key plant mutualists (Irshad et al. 2011; Mao et al. 2006; Trap et al. 2016). Their grazing activity stimulates bacterial growth, especially in the rhizosphere of plants where bacteria proliferate, which enhances the availability of nutrients for plant roots (Anderson et al. 1978; Bonkowski and Clarholm 2012; Irshad et al. 2012). In nutrient-poor soils, the presence of bacterivorous nematodes in the vicinity of roots can significantly increase the competitive advantage of plants over bacteria regarding nutrients (Bjornlund et al. 2012; Trap et al. 2016).

Nematode behaviour is influenced by a wide variety of compounds (ions, amino acids, volatile organic compounds, vitamins, $\mathrm{CO}_{2}$ ), as well as $\mathrm{pH}$ gradients and bacterial food (Anderson and Coleman 1981; Grewal and Wright 1992; Rasmann et al. 2012; Young et al. 1996). Bacterivorous nematodes move along a signal gradient towards the bacteria (Hallem et al. 2011; Rengarajan and Hallem 2016). Such signals are found in the rhizosphere where root facilitates nematode movement (Trap et al. 2015) and root exudates promote bacterial proliferation (el Zahar Haichar et al. 2014) and subsequently attract nematodes (Bais et al. 2006; Horiuchi et al. 2005). In view of the fact that the amount and composition of root exudates varies according to the rice cultivar (Aulakh et al. 2001; Bhattacharyya et al. 2013), we hypothesized that the ability of rice to attract bacterivorous nematodes in its rhizosphere also varies according to the cultivar. We tested this hypothesis using an original threecompartment Petri dish experiment with eight upland rice cultivars growing in a poor-nutrient tropical soil in Madagascar and Acrobeloides sp. as a bacterivorous nematode model species.

\section{Pot experiment}

We sampled the first $10 \mathrm{~cm}$ of a Ferrallitic soil under natural savanna from Lazaina $\left(18^{\circ} 46^{\prime} 55\right.$ $59^{\circ} \mathrm{S}, 47^{\circ} 32^{\prime} 463^{\circ} \mathrm{N}, 1274 \mathrm{~m}$ altitude, Madagascar) in October 2016 . The soil (sandy-clay 


\section{ACCEPTED MANUSCRIPT}

texture, $\mathrm{pH}$ 5.5, C:N 16, Olsen P 4.7 mg.kg ${ }^{-1}$ ) was air-dried until constant weight (7 days) and sieved at $2 \mathrm{~mm}$. Eight upland rice cultivars (Oryza sativa L.) were selected in order to be representative of the large panel of rice cultivars used by famers. (Table 1): B22, FOFIFA 182, FOFIFA 172, FOFIFA 152, FOFIFA 154, NERICA 4, Chhromrong Dhan and WAB 880-1-32-1-1-P2-HB-1. Forty-five pots containing $1 \mathrm{~kg}$ of dry soil were prepared. For each cultivar, three seeds were planted in each pot and five replicates were used. Pots without seeds were used as control. The soil moisture content was maintained at $80 \%$ of water-holding capacity. After 32 days of growth in a greenhouse (mean temperature $28.1^{\circ} \mathrm{C}$; mean and max PAR light 522 and $2378 \mu \mathrm{M} . \mathrm{m}^{2} . \mathrm{s}^{-1}$ between 6:00 am and 6:00 pm), the plants were gently removed from the pot together with their soil. The plants were then held by hand at the shoot collar and dropped $30 \mathrm{~cm}$ high on a plastic tray before being lifted from the tray and placed on a $200 \mu \mathrm{m}$ sieve. The soil remaining on the tray was removed. The root-adhering soil (RAS) was carefully separated from the roots by washing over the sieve with sterile deionized water (constant volume). RAS was air-dried over 7 days before the Petri dish experiment. RAS sampling was carried out by the same person to ensure protocol reproducibility. The plant shoot and root were separated, dried at $60^{\circ} \mathrm{C}$ for 48 hours and weighted. RAS respiration was measured by weighting $20 \mathrm{~g}$ of dry RAS, moistened at $80 \%$ of holding capacity and incubating over 7 days at $28^{\circ} \mathrm{C}$ in the dark within $150 \mathrm{ml}$ hermetic glass flasks (three replicates). At the end of the incubation, the total atmospheric $\mathrm{CO}_{2}$ concentration was measured in all flasks using a micro-CPG (CP-4900, Varian, Middelburg, The Netherlands). Flasks without soil were used as control. $\mathrm{RAS} \mathrm{pH}_{\text {water }}$ was measured after $30 \mathrm{mn}$ of stirring in distilled water (1:2.5 soil:water ratio).

\section{Petri dish experiment}

Monoxenic populations in sterile Petri dishes of Acrobeloides sp. on Escherichia coli were obtained from Lazaina and maintained at $25^{\circ} \mathrm{C}$ in the laboratory following the procedure 


\section{ACCEPTED MANUSCRIPT}

described in Irshad et al. (2011). Acrobeloides is a common ubiquitous genus that dominates

bacterivorous nematodes in upland rice systems in the Malagasy highlands (Djigal et al. 2012;

Villenave et al. 2009). Before use in the Petri dish experiment, nematodes were removed from the breeding TSA plates (by washing the surface with sterile water) and transferred to a fine cellulose wadding paper placed in a Petri plate $(90 \mathrm{~mm}$ diameter) with water during $48 \mathrm{~h}$. Living nematodes will move from the filter paper into the water without agar pollution. Tricompartment Petri dishes ( $90 \mathrm{~mm}$ diameter) were used to test the nematode attractancy of RAS (Fig. 1). Compartment A of the Petri dishes was filled with $7 \mathrm{ml}$ of sterile agarose (10 g. $\mathrm{L}^{-1}$ ) and communicated with the two other compartments by open gates. Compartments B and $\mathrm{C}$ were not connected and were filled with either $10 \mathrm{~g}$ of dry RAS or bulk soil from the five control pots, then moistened with 4.8 or $4.4 \mathrm{ml}$ of distilled water for RAS and bulk soil, respectively. Compartment A was moistened with $200 \mu \mathrm{l}$ of sterile distilled water to favour nematode migration. Around 100 food-deprived nematodes were inoculated on the top of the middle line (dark dashed line in Fig. 1). Petri dishes were incubated in the dark at $25^{\circ} \mathrm{C}$. After 16 hours, the nematodes were counted in the right (r) and left (l) zones of each side of the middle line of the compartment A. For each cultivar, we replicated the experiment five times so as to match the five replicates from the pot experiment. The attractancy was expressed in percentage.

Statistical analyses were performed with R (Team 2016). One-way ANOVA and Tukey HSD post-hoc tests were performed on shoot and root biomass (RB), RAS mass, RAS:RB ratio and RAS respiration. Data normality was checked using the Wilk-Shapiro test. Significance in RAS nematode attractancy was assessed with a binomial test. Pearson correlations were used to test for linear relationships between nematode attractancy and RAS mass.

Bacterivorous nematodes graze on dense bacterial populations that mineralize root exudates, increasing bacterial turnover and nutrient cycling in the rhizosphere of plants (Griffiths 1986; 


\section{ACCEPTED MANUSCRIPT}

Trap et al. 2016). We formulated the hypothesis that the translocation of plant carbon to the soil may be a mechanism by which rice attracts mutualistic nematodes, resulting in a higher respiration. In agreement with this assumption, F172 was the cultivar that exhibited the highest attraction value (61\%) (Fig. 2) and RAS respiration, i.e. 1.5 times more than the bulk soil (Table 2). This hypothesis is also supported by the significant correlation between RAS:RB ratio and nematode attractancy when W880 was excluded from the data set $\left(\mathrm{R}^{2}=\right.$ 0.79, $P$-value 0.006). F152 and F182 attracted fewer nematodes (56\% average) and had lower RAS respiration than F172. Finally, the abilities of rice roots to aggregate the soil and to attract Acrobeloides sp. are thus most likely mediated by high amounts of root exudation (el Zahar Haichar et al. 2014). F172 had also the lowest root biomass (RB) and the highest RAS:RB ratio among cultivars (Table 2), supposing a trade-off between carbon allocation in root biomass and exudates.

Interestingly, we observed that Acrobeloides sp. individuals were significantly more attracted to the bulk soil than the RAS produced by W880 (Fig. 2). W880 did not show lower respiration values than the bulk soil, suggesting that nematode repulsion by W880 RAS was not related to a low rhizodeposition. Likewise, W880 did not alter soil pH as N4 did (Table 2), rejecting the hypothesis that W880 repulsed nematodes by changing soil $\mathrm{pH}$ (Jairajpuri and Azmi 1978). Knowing that nematode movement is also influenced by ions or volatile compounds (Le Saux and Queneherve 2002; Rasmann et al. 2012), it is possible that W880 (i) altered its rhizospheric nutrient concentrations or (ii) produced volatile compounds or favored production of bacterial metabolites acting as repellents (Dusenbery 1983).

To conclude, we showed that plant breeding, already known to affect interactions between rice and plant-parasitic nematodes (Dimkpa et al. 2015), impact the ability of rice to interact with mutualistic bacterivorous nematodes. Increasing production of root exudates by rice cultivars may thus favour nematode recruitment, with possible positive feedbacks for bacterial 


\section{ACCEPTED MANUSCRIPT}

colonization of rhizosphere and nutrient release (Knox et al. 2003). However, the role and involvement of selection criteria in the ability of rice to attract nematodes remains unclear. For instance, nematode attraction did not seem related to the resistance or tolerance against pests (blast rice disease and Striga asiatica), nor to the cultivar ability to grow at specific altitude (Table 1). Screening a larger panel of rice cultivars would be necessary to better link agronomic performance with nematode attractancy. Also, characterizing root exudation of the eight rice cultivars, as well as their nutrient response to bacterivorous nematode inoculation, would constitute useful further investigations to better understand interactions between upland rice genotype diversity, mutualist nematodes and the agronomic outputs.

\section{Acknowledgements}

This work received support from the French state (Labex Agro: ANR-10-LabX-001-01), generated by the National Research Agency under the program "Future Investments". We are grateful to the "Institut de Recherche pour le Développement" (IRD) for having provided a PhD grant to P. Ranoarisoa through the "Allocation de Recherche pour une Thèse au Sud" (ARTS) program. We want to thank K. Rahajaharilaza and H.M. Ralalason for their assistance during root-adhering soil collection and Dr. C. Villenave (ELISOL Environnement, Nîme, France) for nematode identification. 


\section{ACCEPTED MANUSCRIPT}

\section{References}

Anderson RV, Coleman DC (1981) Population development and interactions between 2 species of bacteriophagic nematodes Nematologica 27:6-19

Anderson RV, Elliott ET, McClellan JF, Coleman DC, Cole CV, Hunt HW (1978) Trophic interactions in soils as they affect energy and nutrient dynamics. 3. Biotic interactions of bacteria, amebas, and nematodes Microb Ecol 4:361-371

Aulakh M, Wassmann R, Bueno C, Kreuzwieser J, Rennenberg H (2001) Characterization of root exudates at different growth stages of ten rice (Oryza sativa L.) cultivars Plant Biology 3:139-148

Bais HP, Weir TL, Perry LG, Gilroy S, Vivanco JM (2006) The role of root exudates in rhizosphere interactions with plants and other organisms Annu Rev Plant Biol 57:233266

Bhattacharyya P, Das S, Adhya T (2013) Root exudates of rice cultivars affect rhizospheric phosphorus dynamics in soils with different phosphorus statuses Communications in soil science and plant analysis 44:1643-1658

Bjornlund L, Liu MQ, Rønn R, Christensen S, Ekelund F (2012) Nematodes and protozoa affect plants differently, depending on soil nutrient status European Journal of Soil Biology 50:28-31

Bonkowski M, Clarholm M (2012) Stimulation of plant growth through interactions of bacteria and protozoa: Testing the auxiliary microbial loop hypothesis Acta Protozoologica 51:237-247

Dimkpa SO, Lahari Z, Shrestha R, Douglas A, Gheysen G, Price AH (2015) A genome-wide association study of a global rice panel reveals resistance in Oryza sativa to root-knot nematodes Journal of experimental botany:erv470 


\section{ACCEPTED MANUSCRIPT}

Djigal D, Saj S, Rabary B, Blanchart E, Villenave C (2012) Mulch type affects soil biological functioning and crop yield of conservation agriculture systems in a long-term experiment in Madagascar Soil and tillage research 118:11-21

Dusenbery DB (1983) Chemotactic behavior of nematodes J Nematol 15:168

el Zahar Haichar F, Santaella C, Heulin T, Achouak W (2014) Root exudates mediated interactions belowground Soil Biology and Biochemistry 77:69-80

Grewal P, Wright D (1992) Migration of Caenorhabditis elegans (Nematoda: Rhabditidae) larvae towards bacteria and the nature of the bacterial stimulus Fundamental and applied nematology 15:159-166

Griffiths BS (1986) Mineralization of nitrogen and phosphorus by mixed cultures of the Ciliate protozoan Colpoda steinii, the nematode Rhabditis sp and the bacterium Pseudomonas fluorescens Soil Biology \& Biochemistry 18:637-641

Hallem EA, Dillman AR, Hong AV, Zhang Y, Yano JM, DeMarco SF, Sternberg PW (2011) A sensory code for host seeking in parasitic nematodes Current Biology 21:377-383

Horiuchi J-i, Prithiviraj B, Bais HP, Kimball BA, Vivanco JM (2005) Soil nematodes mediate positive interactions between legume plants and rhizobium bacteria Planta 222:848857

Irshad U, Brauman A, Villenave C, Plassard C (2012) Phosphorus acquisition from phytate depends on efficient bacterial grazing, irrespective of the mycorrhizal status of Pinus pinaster Plant and Soil 358:148-161

Irshad U, Villenave C, Brauman A, Plassard C (2011) Grazing by nematodes on rhizosphere bacteria enhances nitrate and phosphorus availability to Pinus pinaster seedlings Soil Biology \& Biochemistry 43:2121-2126

Jairajpuri M, Azmi M (1978) Aggregation and repulsion of nematodes at $\mathrm{pH}$ gradients Nematologia mediterranea 6:107-112 


\section{ACCEPTED MANUSCRIPT}

Knox OGG, Killham K, Mullins CE, Wilson MJ (2003) Nematode-enhanced microbial colonization of the wheat rhizosphere Fems Microbiology Letters 225:227-233 doi:10.1016/s0378-1097(03)00517-2

Le Saux R, Queneherve P (2002) Differential chemotactic responses of two plant-parasitic nematodes, Meloidogyne incognita and Rotylenchulus reniformis, to some inorganic ions Nematology 4:99-105 doi:10.1163/156854102760082258

Mao X, Hu F, Griffiths B, Li H (2006) Bacterial-feeding nematodes enhance root growth of tomato seedlings Soil Biology \& Biochemistry 38:1615-1622

Raboin L-M et al. (2013) Création variétale pour la riziculture pluviale d'altitude à Madagascar: bilan de 25 années de sélection Cahiers Agricultures 22:450-458

Raboin L-M, Randriambololona T, Radanielina T, Ramanantsoanirina A, Ahmadi N, Dusserre J (2014) Upland rice varieties for smallholder farming in the cold conditions in Madagascar's tropical highlands Field Crops Research 169:11-20

Rasmann S, Ali JG, Helder J, van der Putten WH (2012) Ecology and evolution of soil nematode chemotaxis J Chem Ecol 38:615-628

Rengarajan S, Hallem EA (2016) Olfactory circuits and behaviors of nematodes Current Opinion in Neurobiology 41:136-148

Team R (2016) RStudio: Integrated Development for R.

Trap J, Bernard L, Brauman A, Pablo A-L, Plassard C, Ranoarisoa MP, Blanchart E (2015) Plant roots increase bacterivorous nematode dispersion through nonuniform glassbead media J Nematol 47:296

Trap J, Bonkowski M, Plassard C, Villenave C, Blanchart E (2016) Ecological importance of soil bacterivores for ecosystem functions Plant and Soil 398:1-24 


\section{ACCEPTED MANUSCRIPT}

Villenave C, Rabary B, Chotte J-L, Blanchart E, Djigal D (2009) Impact of direct seeding mulch-based cropping systems on soil nematodes in a long-term experiment in Madagascar Pesquisa Agropecuaria Brasileira 44:949-953

Young I, Griffiths B, Robertson W (1996) Continuous foraging by bacterial-feeding nematodes Nematologica 42:378-382 


\section{ACCEPTED MANUSCRIPT}

Fig. 1. Experimental setup made by three-compartment Petri dish used to assess nematode attractancy to root-adhering soils (RAS) from eight rice cultivars. Compartment A (white area), filled with sterile agarose, was connected to the two others by open gates.

Compartments B (light grey area) and C (dark grey area) were filled with RAS or bulk soil. The black dashed line represents an imaginary line splitting the compartment A in two zones ( $\mathrm{r}$ and $\mathrm{l}$ ). Nematodes were inoculated in the top of the imaginary black dashed line (black arrow).

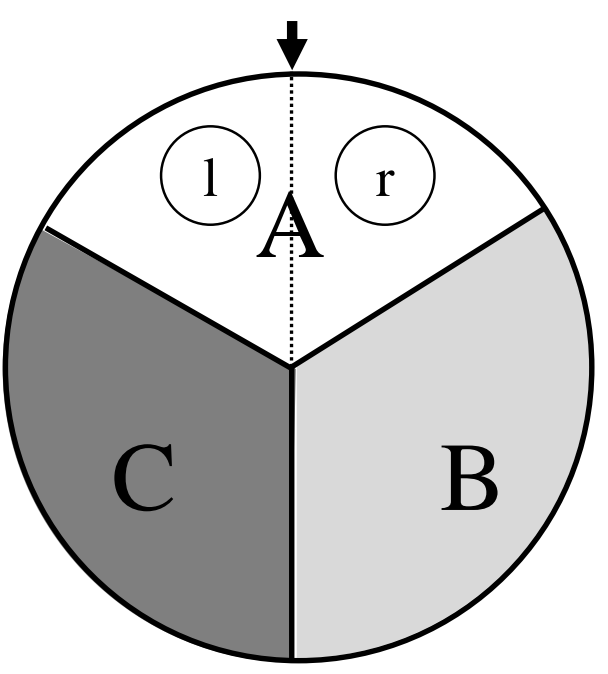




\section{ACCEPTED MANUSCRIPT}

Fig. 2. Attractancy of nematodes to root-adhering soils (RAS) from eight upland rice cultivars (CD, F154, W880, F182, F152, N4, F172 and B22). The horizontal bars correspond to standard deviation. NS: not significant, $* P<0.05 ; * * P<0.01 ; * * * P<0.001$ according to a binomial test (5 replicates).

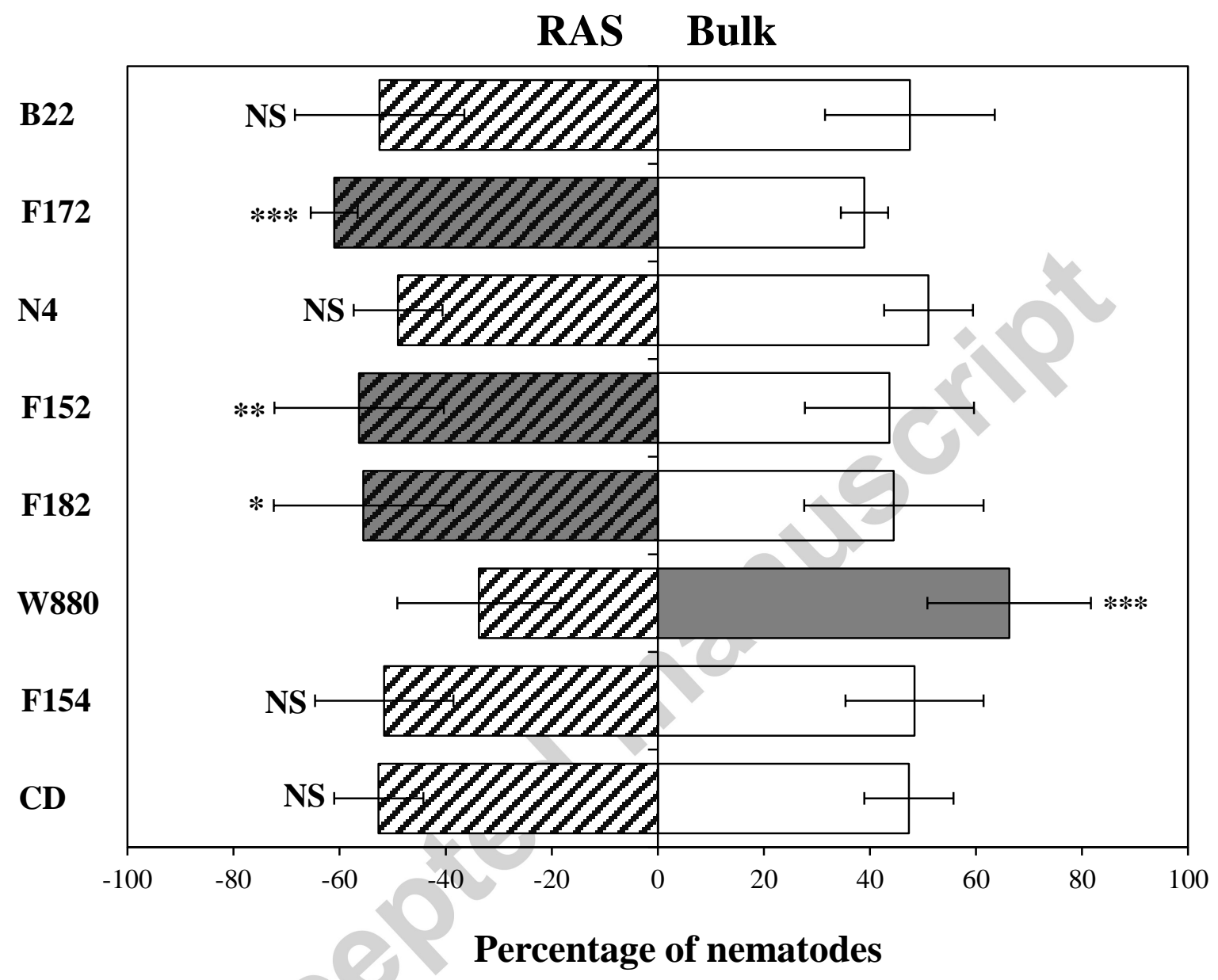

Table 1. Agronomic criteria used in the selection of the eight upland rice cultivars

\begin{tabular}{llll}
\hline Rice cultivars & Selection criteria & $\begin{array}{l}\text { Optimal } \\
\text { altitude for } \\
\text { cropping }\end{array}$ & $\begin{array}{l}\text { Adoption by } \\
\text { farmers } \$\end{array}$ \\
\hline B22 & $\begin{array}{l}\text { Cultivar susceptible to root parasites, } \\
\text { Striga (Striga asiatica) and susceptible } \\
\text { to rice blast disease }\end{array}$ & 700 to $1200 \mathrm{~m}$ & $\begin{array}{l}\text { Highly in some } \\
\text { districts }\end{array}$ \\
\hline
\end{tabular}


FOFIFA 182 Cultivar tolerant to blast rice disease (F182)

FOFIFA 172 Cultivar resistant to blast rice disease (F172)

FOFIFA 152 Cultivar susceptible to blast rice disease 1200 to $1650 \mathrm{~m}$ Abandoned (F152)

FOFIFA 154 Cultivar susceptible to blast rice disease 1200 to $1650 \mathrm{~m}$ Abandoned (F154)

NERICA 4 Cultivar tolerant to root parasites, Striga 700 to $1200 \mathrm{~m}$ (N4) (Striga asiatica)

Chhromrong Cultivar tolerant to rice blast disease, Dhan (CD) optimal culture at an altitude of 1650 to $1900 \mathrm{~m}$.

WAB 880- Cultivar tolerant to blast rice disease

1-32-1-1P2-HB-1 (W880)

\author{
700 to $1200 \mathrm{~m}$ \\ Not yet \\ distributed
}

1200 to $1650 \mathrm{~m}$ Poorly

Highly in some districts

1200 to $1900 \mathrm{~m}$ Very highly

700 to $1200 \mathrm{~m} \quad$ Not yet distributed 


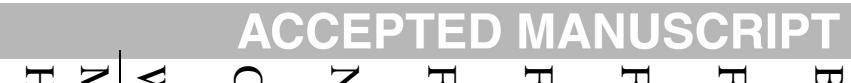

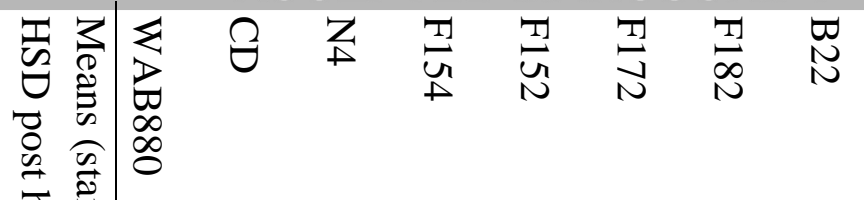

ธิ

$\vec{\nabla}$

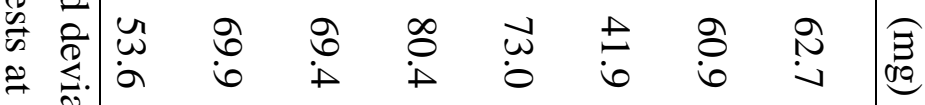
$\nabla \stackrel{\Xi}{\sharp}$.

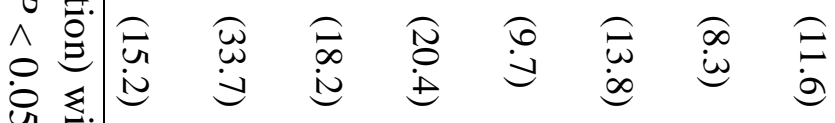

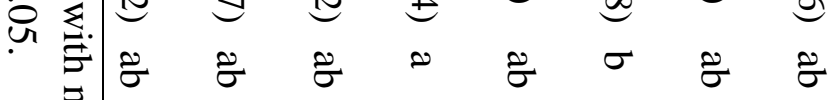
䎡

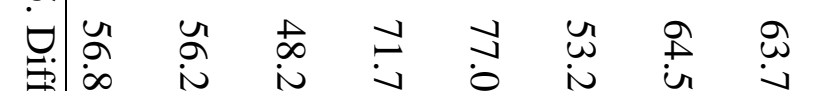

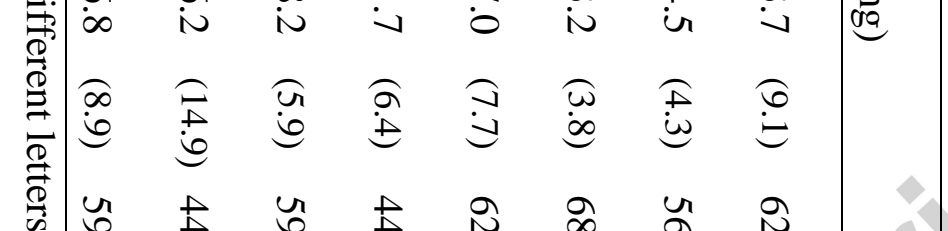

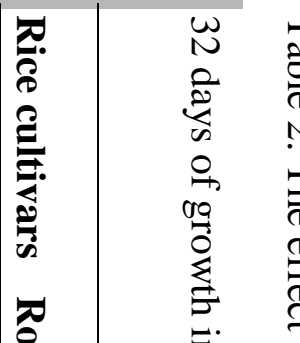

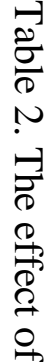

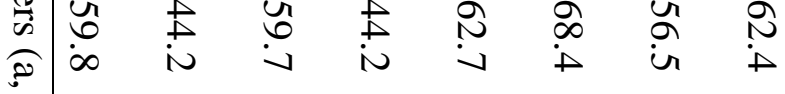

ڤ人

$\sigma 2 \sigma a \sigma a r a$

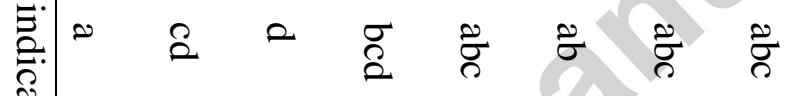

$\stackrel{\vec{D}}{\circ}$

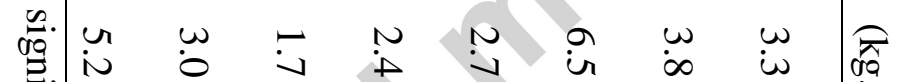

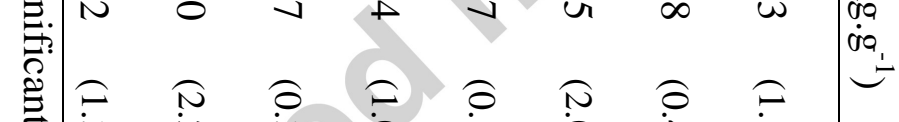

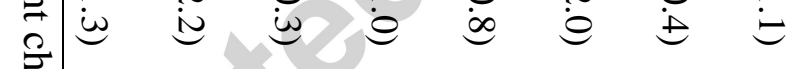

चै ठ 0 ठ

要

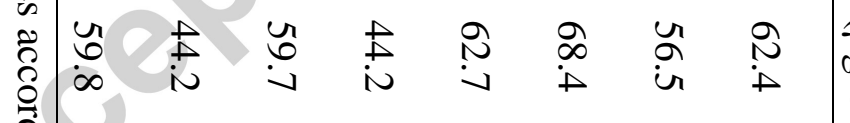

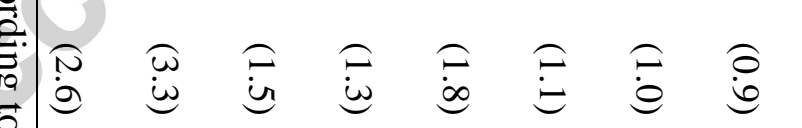

○े

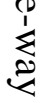

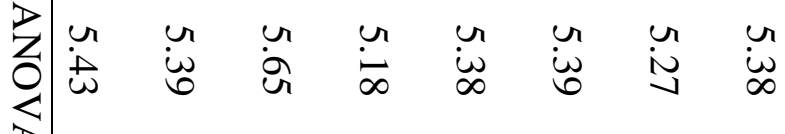

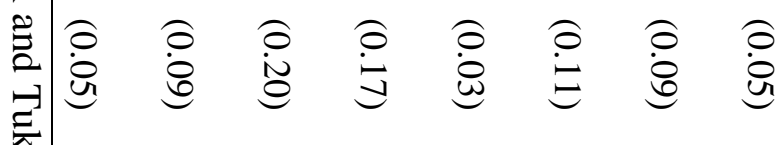

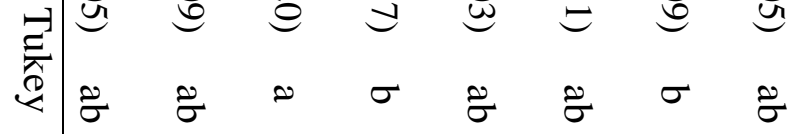

हृ.

三

.

○ 